\title{
Analysis of water state adsorbed by cellulose fibers
}

\author{
(C) Yury B. Grunin, ${ }^{2 *}$ Daria S. Masas, ${ }^{1}$ Maria S. Ivanova, ${ }^{1}$ Tatiana Yu. Grunina, ${ }^{2}$ \\ Gocha Sh. Gogelashvili, ${ }^{1}$ and Alexander S. Maslennikov ${ }^{1}$ \\ ${ }^{1}$ Volga State University of Technology. Lenin St., 3. Yoshkar-Ola, 424000. Russia. \\ Phone: +7 (8362) 68-68-64. \\ ${ }^{2}$ Moscow State University. Lomonosov Lenin Hills, 1. Moscow, 119991. Russia. \\ Phone:+7 (495) 939-10-00. E-mail: GruninYB@volgatech.net
}

\begin{abstract}
*Supervising author; ${ }^{+}$Corresponding author
Keywords: cellulose; supramolecular structure; adsorption; NMR relaxation; biopolymer-water system; Gibbs adsorption layer.
\end{abstract}

\begin{abstract}
Modernized model of microfibril cellulose layered structure is proposed. This model considers presence of slit-shaped micropores in space between elementary fibrils and cellulose microfibrils. It is discussed the nature of donor-acceptor hydrogen bonds formation: intra-, intermolecular, and interlayer bonds inherent in each glucopyranous cellulose link. It's described the mechanism of water molecules specific adsorption interactions in a monolayer with active centers located on the hydrophilic surfaces of elementary fibrils. Dipole-dipole energy transition into energy of hydrogen bond is discussed during adsorption process between active centers of cellulose and water adsorptive molecules. Analysis of water molecules dipole-dipole interactions with surface hydroxyl groups of cellulose showed that at distance of 2.5-3 $\AA$ energy of this interaction transforms into energy of hydrogen bond. It is discussed the formation mechanism of water molecules donor-acceptor bonds with cellulose surface hydroxyl groups. Thermodynamic parameters characterizing adsorbate state the in these layers are determined by proton magnetic relaxation and sorption measurements. It's established the possibility of determining adsorption net heat in bilayer considering Arrhenius nature of adsorbate thermal molecular motions correlation times. Increase in entropy of adsorbed water during adsorption process is revealed basis on Vant Hoff equation and certain adsorption equilibrium constant. The calculation established that distance between nearest active centers of cellulose is $6.5 \AA$. This leads to disunity of adsorbed water molecules and allows application of Langmuir and BET adsorption theory. Analysis of spin-lattice relaxation times dependence on cellulose moisture content made it possible to establish the cause of its crystallite wedging from adsorbed water molecules at adsorption initial stages. Decline of the spin-lattice relaxation unambiguously indicates the process of cellulose dispersion into its structural elements. It was established that during adsorption a part of the internal regions of crystallites passes to their surface with participation of cellulose hydroxyl groups. During desorption reverse process is observed.
\end{abstract}

\section{References}

[1] S.J. Gregg, K.S.W. Sing. Adsorption, surface area and porosity. Academic Press. 1982. (russian)

[2] Y.B. Grunin, L.Y. Grunin, D.S. Masas et al. Russian Journal of Physical Chemistry A. 2016. Vol.90. Iss.11. P.2249-2253. (russian)

[3] Yu.B. Grunin, L.Yu. Grunin, E.A. NikolSkaya et al. Russian Journal of Physical Chemistry A. 2013. Vol.87. Iss.1. P.100-103. (russian)

[4] Yu.B. Grunin, L.Y. Grunin, E.A. Nikolskaya, and D.S. Masas. The possibility of proton magnetic relaxation in the analysis of the Gibbs adsorption of water on plant polymers. Butlerov Communications. 2014. Vol.39. No.9. P.39-45. ROI: jbc-02/14-39-9-39

[5] Yu.B. Grunin, L.Yu. Grunin, E.A. Nikolskaya. Russian Journal of Physical Chemistry A. 2007. Vol.81. Iss.7. P.1165-1169. (russian)

[6] Z.T. Valishina, G.N. Galiullina, and A.V. Kostochko. Structure and properties of modified cellulose. Butlerov Communications. 2015. Vol.42. No.5. P.104-111. DOI: 10.37952/ROI-jbc-01/15-42-5-104

[7] L.S. Kocheva, A.P. Karmanov, and I.I. Shuktomova. Physical-mechanical properties of cellulose-fibrous materials and the influence on them of the $\gamma$-radiation. Butlerov Communications. 2018. Vol.55. No.8. P.46-52. DOI: 10.37952/ROI-jbc-01/18-55-8-46

[8] Gerasimov, Ya.I. Course of physical chemistry. Moscow: Chemistry. 1970. (russian)

[9] M.Ya. Ioelovich. Polymer Science Series A. 2016. Vol.58. Iss.6. P.925-943. (russian) 
[10] E.E. Dosadina, E.E. Savelyeva, A.Y. Evdokimenko, L.L. Brkich, D.A. Bidanov, E.O. Medusheva, N.V. Pyatigorskaya, G.E. Brkich, and A.A. Belov. Prolonged biomedical materials based on modified cellulose. Butlerov Communications. 2017. Vol.50. No.5. P.109-117. DOI: 10.37952/ROI-jbc-01/1750-5-109

[11] L.Y. Grunin, Y.B. Grunin, N.N. Sheveleva et al. Biophysics. 2017. Vol.62. Iss.2. P.198-206. (russian)

[12] O.V. Nesterova, E.N. Cherezova, M.A. Torlopov, I.S. Martakov, and E.V. Udoratina. The modification process investigation of the of cellulose modificationproducts on SKI-3 elastomer and it is based on rubbers. Butlerov Communications. 2016. Vol.48. No.12. P.127-132. DOI: 10.37952/ROI-jbc-01/16-48-12-127

[13] V.P. Nikolaev, A.A. Ageev, Yu.G. Frolov. Proceedings of Moscow University of Chemical Technology after D.I. Mendeleev. 1978. Vol.101. P.84-101. (russian)

[14] NMR analyzer «Spin Track». URL: www.nmr-design.com

[15] A. Abragam. The principles of nuclear magnetism. Oxford. Clarendon Press. 1961.

[16] V.I. Chizhik. Quantum physics: magnetic resonance and its applications. St. Petersburg: St. Petersburg State. Univ. 2009. (russian)

[17] Y.B. Grunin, L.Y. Grunin, E.A. Nikolskaya et al. Polymer Science, Ser. A. 2012. Vol.54. Iss.3. P.201208. (russian)

[18] L.Yu. Grunin, Y.B. Grunin, V.I. Talantsev et al. Polymer Science, Series A. 2015. Vol.57. Iss.1. P.4351. (russian)

[19] Y.B. Grunin, L.Yu. Grunin, V.I. Talantsev et al. Biophysics. 2015. Vol.60. Iss.1. P.43-52. (russian)

[20] I.Ya. Slonim, A.N. Lyubimov. Nuclear magnetic resonance in polymers. Moscow: Chemistry. 1969. (russian)

[21] Yu.B. Grunin, L.Yu. Grunin, D.S. Masas, V.I. Talantsev, and N.N. Sheveleva. Study of cellulose structure and its hydrophilic properties by NMR ${ }^{1}$ H. Butlerov Communications. 2016. Vol.47. No.8. P.115-124. DOI: 10.37952/ROI-jbc-01/16-47-8-115

[22] E. Cartmell, G.W.A. Fowles. Valency and molecular structure. Butterworths. 1979. (russian)

[23] G.M. Bartenev, Yu.V. Zelenev. Course of polymers physics. Ed. prof. S.Y. Frenkel. Leningrad: Chemistry. 1976. (russian)

[24] A.V. Kisslev. Intermolecular interactions in adsorption and chromatography. Moscow: Higher School. 1986.

[25] Yu.B. Grunin, M.S. Ivanova, T.Y. Grunina, G.Sh. Gogelashvili, and D.S. Masas. The nature of supramolecular structure changes and hydrophilic properties of cellulose in adsorption-desorption processes. Butlerov Communications. 2018. Vol.56. No.12. P.10-16. DOI: 10.37952/ROI-jbc-01/18-56$12-10$

[26] M.M. Dubinin. Journal of Physical Chemistry. 1987. Vol.5. P.1301. (russian) 